\title{
FAKTOR YANG MEMPENGARUHI KECANDUAN GADGET TERHADAP PERILAKU REMAJA
}

\author{
Rezky Graha Pratiwi ${ }^{1}$, Rosyidah Umpu Malwa ${ }^{2}$ \\ Fakultas Psikologi, Sekolah Tinggi Ilmu Psikologi Abdi Nusa Palembang ${ }^{12}$ \\ Jalan Veteran No.1 Palembang \\ Surel : rezkygraha70@gmail.com ${ }^{1}$, rosyidahumpumalwa2@ gmail.com ${ }^{2}$
}

\begin{abstract}
This study aims to determine how big the influence of gadget addiction on the behavior of class VIII students at Mts Ma'Ariful Ulum Talang Keramat Banyuasin. The hypothesis proposed in this study is that there is an influence between gadget addiction on the behavior of class VIII students at Mts Ma'Ariful Ulum Talang Keramat Banyuasin. The population in this study was all students of class VIII as many as 110 students, the subjects of this study were 55 students and random sampling technique. Collecting data using addiction and behavior scales, data processing techniques using SPSS. The results of the regression analysis showed $R$ square $=0.277, F=20.286$ and $p=0.000$ ( $p<0.05$ ) with $N=55$ and an rtable of 0.266. This shows that addiction has an influence on behavior. Thus, the hypothesis of this study can be accepted that the contribution of addiction to behavior is $27.7 \%$.
\end{abstract}

\section{Keywords : Gadget Addiction, Behavior, Adolescent}

\begin{abstract}
Abstrak : Penelitian ini bertujuan untuk mengetahui seberapa besar Pengaruh Kecanduan Gadget Terhadap Perilaku Siswa Kelas VIII Di Mts Ma'Ariful Ulum Talang Keramat Banyuasin. Hipotesis yang diajukan pada penelitian ini adalah bahwa terdapat pengaruh antara kecanduan gadget terhadap perilaku siswa kelas VIII di Mts Ma'Ariful Ulum Talang Keramat Banyuasin. Populasi dalam penelitian ini adalah seluruh siswa kelas VIII sebanyak 110 siswa, subjek penelitian ini sebanyak 55 siswa dengan menggunakan teknik random sampling. Pengumpulan data menggunakan skala kecanduan dan perilaku, teknik pengolahan data menggunakan SPSS. Hasil analisis regresi menunjukan $\mathrm{R}$ square $=0,277, \mathrm{~F}=20,286$ dan $\mathrm{p}=0,000(\mathrm{p}<0,05)$ dengan $\mathrm{N}=55$ dan $\mathrm{r}_{\text {tabel }}$ sebesar 0,266 . Hal ini menunjukan bahwa kecanduan memiliki pengaruh terdahap perilaku. Dengan demikian, hipotesis penelitian ini dapat diterima kontribusi kecanduan terhadap perilaku adalah sebesar $27,7 \%$
\end{abstract}

Kata Kunci: Kecanduan Gadget, Perilaku, Remaja

\section{PENDAHULUAN}

Remaja merupakan masa perubahan atau peralihan dari anak-anak ke masa dewasa yang meliputi perubahan biologis, perubahan psikologis, dan perubahan sosial (Sofia \& Adiyanti, 2013). WHO (World Health Organization) menetapkan batasan usia dari remaja adalah berkisar antara 10-20 tahun.
Pada era yang modern seperti sekarang ini, banyak dijumpai bahwa kecanggihan teknologi dan informasi dunia saat ini berkembang sangatlah pesat. Banyak nya teknologi canggih yang diciptakan saat ini, salah satunya yaitu gadget. Diera perkembangan teknologi, khususnya 
teknologi informasi, gadget sudah berkembang dengan pesat.

Berdasarkan data Asosiasi Pengguna Jaringan Internet Indonesia (APJII), terjadi peningkatan penggunaan internet di Indonesia. Pada tahun 2019, APJII merilis data jumlah pengguna gadget di Indonesia tahun 2018, jumlah pengguna gadget mencapai 171,17 juta jiwa dari 264,16 juta penduduk Indonesia atau $64,8 \%$ penduduk Indonesia.

Data survey APJII (2019) menunjukkan bahwa kelompok usia 10 sampai dengan umur 14 tahun mengalami peningkatan penggunakan gadget sebesar 66,52\%. Hasil ini menunjukkan bahwa remaja awal mengalami peningkatan penggunaan gadget tertinggi dan menunjukkan bahwa sebagian besar remaja telah menjadi pengguna gadget.

Penelitian yang dilakukan oleh (Laurintia, 2019) bahwa pengaruh yang ditimbulkan dari penggunaan gadget bagi para siswa, sekitar $80 \%$ siswa mengabaikan lingkungan sosial sekitarnya, walaupun mereka sedang menggunakan gadget.

Penggunaan gadget bagi remaja dapat membawa dampak positif maupun negatif seperti membantu dalam proses belajar mereka, memudahkan dalam berkomunikasi dengan teman atau keluarganya, serta membantu mereka dalam mendapatkan semua informasi. Dampak negatif dari penggunaan gadget seperti mereka yang berlebihan dalam penggunaan gadget akan mempengaruhi proses belajar siswa seperti malas belajar, dan banyak menghabiskan waktu mereka dengan gadget, dikatakan oleh (Agusta, 2016)

Nikmah (2010) menjelaskan bahwa kecanduan tidak hanya terhadap zat saja, akan tetapi juga pada aktivitas tertentu yang dilakukan berulang-ulang dan menimbulkan dampak negatif begitupun dengan kecanduan terhadap gadget. Hal ini akan menghambat proses sosialisasi anak dan akan menimbulkan ketergantungan pada gadget tersebut.

Salah satu faktor yang mempergaruhi kecanduan gadget adalah perilaku (tindakan) atau aktivitas dari manusia itu sendiri. Menurut Gerungan (2005) mengatakan perilaku adalah sikap terhadap objek tertentu, bisa berupa sikap pandangan atau sikap perasaan. Tetapi sikap yang disertai dengan kecenderungan untuk bertindak sesuai dengan sikap terhadap objek tadi. Sehubungan pendapat Arifin (2015) mengatakan bahwa sikap atau perilaku adalah suatu kecenderungan yang mendorong seseorang untuk bertingkah laku yang dituju ke arah suatu objek khusus.

Menurut (Notoatmojo. 2010: 134) perilaku dapat dibedakan menjadi dua yaitu perilaku tertutup (convert behavior) dan perilaku terbuka (overt behavior). Perilaku tertutup merupakan respon seseorang terhadap stimulus dalam bentuk terselubung atau tertutup (convert). Perilaku terbuka merupakan respon seseorang terhadap 
stimulus dalam bentuk tindakan nyata atau terbuka.

Hasil penelitian yang dilakukan oleh Asif dan Ramadi (2017) bahwa terdapat hubungan tingkat kecanduan gadget dengan gangguan emosi dan perilaku remaja usia 11-12 tahun yang salah satu hasil perkembangan teknologi yang diciptakan dalam bentuk perangkat kecil. Kecanduan gadget dapat berdampak pada perkembangan anak dan remaja yaitu gangguan emosi dan perilaku.

Sedangkan penelitian yang dilakukan oleh Irawan (2013) bahwa hampir semua siswa MI kelas $\mathrm{V}$ mempunyai perilaku mereka dalam menggunakan gadget sebanyak $44 \%$ game online, $31 \%$ youtube, $19 \%$ instagram, $3 \%$ whatsapp, dan 3\% facebook. Durasi mereka bermain gawai sebanyak $11 \% \leq 1$ jam, $42 \% 1$ 2 Jam, dan $47 \% \geq 2$ jam.

Fitriana (2020) bahwa remaja menggunakan gadget selama 5-7 jam atau 300-420 menit dalam sehari, yang mengakibatkan remaja tersebut sudah mengalami kecanduan tergadap gadget. Penggunaan gadget yang berlebihan memberi dampak negatif bagi perilaku remaja dalam keluarga, seperti ketidakstabilan emosional yang mengakibatkan remaja mudah marah, emosi, gelisah, dan bahkan menggurung diri akibat dijauhkan dari gadget.

Fenomena yang ada di MTS Ma'Ariful Ulum bahwa siswa yang ada di sekolahan tersebut lebih banyak yang menggunakan gadget ketimbang mengutamakan belajar. Dengan Penggunaan gadget menyebabkan remaja menjadi kurang bersosialisasi, hal tersebut terjadi pada siswa maupun siswi mts ma'ariful ulum yang mengalami perubahan sosial sehingga berdampak pada pola kehidupan sehari-hari.

Dari permasalahan diatas, peneliti tertarik untuk melakukan penelitian mengenai kecanduan gadget dan perilaku pada siswa. Adapun rumusan masalahnya adalah apakah ada pengaruh kecanduan internet terhadap perilaku siswa di Mts Ma'Ariful Ulum. Dan tujuan penelitian ini untuk mengetahui pengaruh kecanduan gadget terhadap siswa di Mts Ma’ Ariful Ulum

\section{METODOLOGI PENELITIAN}

Jenis penelitian ini dilakukan secara kuantitatif dengan desain penelitian regresi sederhana. Penelitian untuk membuktikan teori kebenaran, membangun fakta, menunjukkan hubungan antar variabel, memberikan deskripsi statistik, menaksir dan meramalkan hasilnya dengan prosedur penelitian yang sistematis, datanya berupa numerikal dan dianalisis dengan prosedur statistik.

Populasi dalam penelitian ini menggunakan random sampling dimana, sampel yang diambil hanya sebanyak 55 responden dan subjek dalam penelitian ini adalah seluruh siswa kelas VIII sebanyak 110 
orang siswa di Mts Ma'Ariful Ulum Talang Keramat Banyuasin.

Pada penelitian ini metode pengumpulan data terdiri dari skala psikologi, berupa daftar pertanyaan yang akan dikenakan pada subjek penelitian. Aitem-aitem dalam skala berupa pernyataan favourable dan unfavourable. Aitem favourable merupakan pernyataan yang mendukung, memihak, atau menunjukkan ciri adanya atribut yang diukur.Sebaliknya, aitem tak favourable berupa pernyataan tidak mendukung atau tidak menggambarkan ciri atribut yang diukur. Metode perskalaan yang digunakan sebagai dasar penelitian nilai skala adalah metode summated rating, yang dikenal dengan skala likert (Curenton,2008).

Skala yang akan dikembangkan dalam penelitian ini adalah skala likert. Jawaban setiap item pernyataan yang menggunakan skala likert mempunyai gradasi dari sangat positif sampai sangat negatif (Sugiono,2014:93). Respon yang diharapkan dari pada subjek adalah taraf persetujuan atau tidak setuju yang telah dimodifikasi dari bentuk aslinya, yang pada awalnya terdiri dari lima katagori pilihan jawaban. Namun setelah dimodifikasi dengan menghilangkan kategori pilihan jawaban yang berada ditengah "raguragu" maka pada setiap butir pernyataan ataupun pertanyaan yang akan diberikan kepada responden akan ada empat alternative pilihan jawaban saja yaitu Sangat Sesuai (SS),
Sesuai (S), Tidak Sesuai ( TS), Sangat Tidak Sesuai (STS).

\section{HASIL DAN PEMBAHASAN}

\section{Hasil Uji Skala X}

Koefisien korelasi dikatakan valid jika $\left(r_{i x}\right) \geq 0,266$ dan dikatakan tidak valid jika $\left(r_{i x}\right)$ $<0,266$. Berdasarkan uji validitas dapat disimpulkan bahwa sebagian besar aitem pertanyaan untuk mengukur masing-masing variabel penelitian dinyatakan valid. Koefisien aitem atau nilai validitas berkisar antara 0,281 hingga 0,686 .

Menurut Sujarweni (2014), apabila nilai Cronbach's Alpha> 0,60 maka kuisioner atau angket dinyatakan reliable atau konsisten, sementara jika nilai Cronbach's Alpha $<0,60$ maka kuisioner atau angket dinyatakan tidak reliable atau tidak konsisten. Hasil uji reliabilitas menunjukan bahwa nilai cronbach's alpha pada variabel bebas yang diteliti lebih besar dari 0,6 yaitu 0,845

\section{Hasil Uji Skala Y}

Koefisien korelasi dikatakan valid jika $\left(r_{i x}\right) \geq 0,266$ dan dikatakan tidak valid jika $\left(r_{i x}\right)$ $<0,266$. Berdasarkan uji validitas dapat disimpulkan bahwa sebagian besar aitem pertanyaan untuk mengukur masing-masing variabel penelitian dinyatakan valid. Koefisien 
aitem atau nilai validitas berkisar antara 0,274 hingga 0,620 .

Menurut Sujarweni (2014), apabila nilai Cronbach's Alpha> 0,60 maka kuisioner atau angket dinyatakan reliable atau konsisten, sementara jika nilai Cronbach's Alpha< 0,60 maka kuisioner atau angket dinyatakan tidak reliable atau tidak konsisten. Hasil uji reliabilitas menunjukan bahwa nilai cronbach's alpha pada variabel bebas yang diteliti lebih besar dari 0,6 yaitu 0,814 .'

\section{Deskripsi Statistik Data Penelitian}

Hasil perhitungan statistic terhadap skala kecanduan didapatkan berdasarkan data yang diperoleh dari rekapitulasi (skor total) jawaban skala. Dari 55 responden didapatkan nilai mean 66,13 , nilai median 63 , standar deviasi 11,161, nilai maksimum 95 dan minimum 38 .

Hasil perhitungan statistic terhadap skala perilaku didapatkan berdasarkan data yang diperoleh dari rekapitulasi (skor total) jawaban skala. Dari 55 responden didapatkan nilai mean 65,11, nilai median 64, standar deviasi 8,381, nilai maksimum 83 dan minimum 47.

\section{Uji Persyaratan Data}

Uji normalitas data digunakan untuk menguji apakah nilai residual yang dihasilkan dari regresi terdistribusi secara normal atau tidak. Didapatkan bahwa nilai signifikansi (2 tailed) untuk variabel kecanduan sebesar 0,413 dan untuk variabel perilaku sebesar 0,621 (p > 0,05). Maka dari itu dapat dikatakan bahwa data terdistribusi dengan normal.

Uji linearitas dilakukan untuk mengetahui hubungan antara variabel yang sifatnya secara linear atau tidak secara signifikan maka pengujian ini bertujuan untuk melihat apakah data dapat ditarik garis lurus sehingga menunjukan hubungan linier dan dapat dikorelasikan. Berdasarkan hasil uji linearitas menggunakan Linearity pada kedua variabel penelitian didapatkan nilai signifikansi linearitas sebesar 0,000 ( $\mathrm{p}<0,05)$. Sehingga dapat disimpulkan bahwa kedua variabel pada penelitian ini memiliki korelasi yang linear.

Uji hipotesis yang digunakan adalah uji T. Teknik ini untuk mengetahui apakah variabel independen $(\mathrm{X})$ berpengaruh secara signifikan terhadap variabel dependen (Y). Pada tabel anova menunjukan bahwa nilai signifikan antara variabel bebas (kecanduan) terhadap variabel terikat (perilaku) adalah $0.000(\mathrm{p}<0.05)$. Maka dari itu terdapat pengaruh antara variabel bebas ke variabel terikat. Lalu karena nilai $\mathrm{T}$ hitung untuk kecanduan gadget sebesar 43,942> T tabel 2,005 maka $\mathrm{H}_{\mathrm{o}}$ ditolak dan $\mathrm{H}_{\mathrm{a}}$ diterima. Lalu nilai $\mathrm{T}$ hitung perilaku sebesar 57,611 > T tabel 2,005 maka $\mathrm{H}_{\mathrm{o}}$ juga ditolak dan $\mathrm{H}_{\mathrm{a}}$ diterima. 


\section{Pembahasan}

Hasil yang peneliti dapatkan sesuai dengan beberapa penelitian terdahulu, yaitu Asif dan Rahmadi (2017) bahwa terdapat hubungan tingkat kecanduan gadget dengan perilaku remaja usia 11-12 tahun yang salah satu hasil perkembangan teknologi yang diciptakan dalam bentuk perangkat kecil (handphone).

Lebih lanjut dijelaskan bahwa kecanduan gadget dapat berdampak pada perkembangan anak dan remaja yaitu gangguan emosi dan perilaku. Selanjutnya Fitriana (2020) mengungkapkan bahwa remaja menggunakan gadget selama 5 hingga 7 jam atau 300 hingga 420 menit dalam sehari, yang mengakibatkan remaja tersebut sudah mengalami kecanduan terhadap gadget. Lebih lanjut dijelaskan bahwa pengunaan gadget yang berlebihan memberi dampak negative bagi perilaku remaja dalam keluarga, seperti ketidakstabilan emosional yang mengakibatkan remaja mudah marah, emosi, gelisah, hingga mengurung diri akibat dijauhkan dari gadget.

Berdasarkan pengamatan oleh peneliti di MTS Ma'ariful Ulum bahwa siswa-siswi yang ada di sekolah tersebut lebih banyak menggunakan gadget daripada mengutamakan belajar. Dengan pengunaan gadget menyebabkan remaja menjadi kurang bersosialisasi dan menghabiskan sebagian besar waktunya dengan memainkan gadget dan membawa gadget kemanapun mereka pergi.

Walaupun sekolah sudah melarang untuk membawa gadget, namun siswa-siswa MTS Ma'ariful Ulum tetap membawanya walaupun secara diam-diam.

Dari hasil uji hipotesis tersebut maka hipotesis yang diajukan pada penelitian ini dapat diterima, sehingga dinyatakan ada pengaruh kecanduan gadget terhadap perilaku siswa kelas VIII di MTS Ma'Ariful Ulum. Berdasarkan uraian diatas dapat ditarik kesimpulan bahwa kecanduan gadget berpengaruh negative terhadap perilaku remaja. Hal ini menunjukan bahwa semakin tinggi kecanduan gadget, maka perilaku siswasiswi akan semakin negative, begitu pula sebaliknya bahwa semakin rendah kecanduan gadget maka perilakunya semakin positif.

\section{SIMPULAN}

Berdasarkan hasil pengujian yang telah dilakukan terhadap permasalahan yang telah dirumuskan dalam hipotesis penelitian, maka dapat disimpulkan bahwa kecanduan gadget berpengaruh secara signifikan terhadap perilaku pada siswa kelas VIII di MTS Ma'Ariful Ulum. Hal ini dapat terlihat dari hasil hipotesis yang diajukan pada penelitian ini adalah bahwa terdapat pengaruh antara kecanduan gadget terhadap perilaku siswa 
kelas VIII di Mts Ma'Ariful Ulum Talang

Keramat Banyuasin.

\section{DAFTAR RUJUKAN}

Asif dan Ramadi 2017. Tentang Hubungan Tingkat Kecanduan Gadget Dengan Gangguan Emosi Dan Perilaku Remaja Usia 11-12 Tahun. Jurnal kedokteran diponegoro Volume 6 No. 2, April 2017 ISSN Online : 2540-8844

Asosiasi Penyelenggara Jasa Internet Indonesia [APJII]. 2014. Profil Pengguna Internet Indonesia Mencapai 171, 71 atau 64,8\%. Jakarta: Asosiasi Penyelenggara Jasa Internet Indonesia.

Arifin, 2015. Perilaku Remaja Pengguna Gadget. IAIT Kediri. Volume 26 Nomor 2 September 2015 287, 26 September, 287-315.

Agusta 2016. Faktor-faktor risiko kecanduan menggunakan smartphone pada siswa di SMK negeri 1 kalasan yogyakarta. EJournal Bimbingan dan Konseling, Volume 3 No. 5. Hal.86-96.

Curenton, S. M. (2008). Early childhood leaders and literacy. Early childhood research quarterly, 23, 597-598. doi: 10.1016/j.ecresq.2008.03.002

Fitriana 2020. Pengaruh Pengguan Gadget Terhadap Perilaku Remaja Dalam Keluarga. Psikoislamedia Jurnal Psikologi Vol, 5 No. 2

Irawan 2013. Pengaruh Kegunaan Gadget terhadap Kemampuan Bersosialisasi pada Remaja. Fakultas Psikologi.Universitas Islam Riau

Gerungan 2005. Dalam Buku Psikologi Sosial Mengatakan Attitude Atau Perilaku. Depdikbud, Kamus Besar Bahasa Indonesia, (Jakarta: Perum Balai Pustaka, 1988), hlm. 671

Laurintia.2019. Hubungan tingkat Kecanduan Gadget dengan. Kualitas 
Tidur pada Siswa. Jurnal Kedokteran 2019, 8(4): 12-17. ISSN 2301-5977, e-ISSN 2527-7154.

Notoatmodjo, (2010). Ilmu Perilaku Kesehatan. Jakarta : Rineka Cipta

Nikmah, Astin. 2010. Dampak Penggunaan Hand Phone Terhadap Prestasi Siswa. E-Jurnal Dinas Pendidikan Kota Surabaya; Volume 5: ISSN : 23373253.

Sujarweni, V. Wiratna 2014. Metode Penelitian: Lengkap, Praktis Dan Mudah Dipahami. Yogyakarta: Pustaka Baru Press

Sugiyono. (2014). Metode Penelitian Pendidikan Pendekatan Kuantitatif,. Kualitatif, dan R\&D. Bandung: Alfabeta.

Sofia, A. dan Adiyanti, M.G. 2013. Hubungan Pola Asuh Otoritatif Orang Tua Dan Konformitas Teman Sebaya Terhadap Kecerdasan Moral.

WHO (World Health Organization).
Pengertian
http://digilib.uinsby.ac.id/

